\title{
Effect of different dose of fertilizer on yield and quality of chilli and soil biological properties available nutrients after harvest of the crop
}

Irappa N. Nagaral and V. B Kuligod

Received : 20.09.2018; Revised : 07.11.2018; Accepted : 16.11.2018

MEMBERS OF RESEARCH FORUM:

Corresponding author : Irappa N. Nagaral, Department of Soil Science and Agriculture Chemistry, College of Agriculture, Dharwad (Karnataka) India Email: nagaral_agri@yahoo.co.in
Co-authors :

V. B Kuligod, Department of Soil Science and Agriculture Chemistry, College of Agriculture, Dharwad (Karnataka) India

\section{Summary}

A field experiment was conducted during Kharif 2011 at a farmer's field in Koliwad (Hubli taluk) village in Northern transitional Zone of Karnataka which is located between $15^{\circ} 21^{\prime} \mathrm{N}$ latitude and $75^{\circ} 24^{\prime} \mathrm{E}$ longitudes and at an altitude of $629 \mathrm{~m}$ above mean sea level (MSL). In the STCR dose of NPK ( $\mathrm{T}_{2}: 216: 116: 166, \mathrm{~N}: \mathrm{P}_{2} \mathrm{O}_{5:} \mathrm{K}_{2} \mathrm{O} \mathrm{kg} \mathrm{ha}{ }^{-1}$, respectively) treatment, higher dry fruit yield of chilli was obtained. Yield increased from $763\left(\mathrm{~T}_{1}: 100: 50: 50 \mathrm{~kg} \mathrm{~N}: \mathrm{P}_{2} \mathrm{O}_{5}: \mathrm{K}_{2} \mathrm{O}\right)$ to $1257\left(\mathrm{~T}_{2}\right) \mathrm{kg} \mathrm{ha}^{-1}$ in soil test based fertilizer application by registering an increase of 39 per cent. This was due to considerably higher level of fertilizer application compared to other

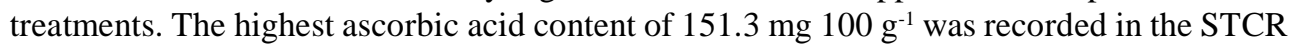
dose of NPK $\left(\mathrm{T}_{2}\right)$ and it was at par with soil test based $\mathrm{N}$ and $\mathrm{K} \pm 50 \%$ and $\mathrm{P} \pm 25 \%\left(\mathrm{~T}_{5}\right)(149.5$ mg $\left.100 \mathrm{~g}^{-1}\right)$. Phosphatase activity $\left(14.12 \mu \mathrm{g} \mathrm{g}^{-1} \mathrm{~h}^{-1}\right)$ was significantly higher in PSB treated plot $\left(\mathrm{T}_{6}\right)$ which also received $\mathrm{N}$ and $\mathrm{K}$ as per $\mathrm{STL}+75 \%$ of RDP under medium level of $\mathrm{P}$ test values compared to untreated plots.

Key words : Biological properties, Soil fertility status, Chilli, Soil organic carbon, Quality parameter

How to cite this article : Nagaral, Irappa N. and Kuligod, V.B. (2018). Effect of different dose of fertilizer on yield and quality of chilli and soil biological properties available nutrients after harvest of the crop. Asian J. Soil Sci., 13 (2) : 114-119 : DOI : 10.15740/HAS/AJSS/13.2/114-119. 